\section{Virus infections of honeybees Apis Mellifera}

\author{
Giuseppina Tantillo, ${ }^{1}$ Marilisa Bottaro, \\ Angela Di Pinto, ${ }^{1}$ Vito Martella, ${ }^{1}$ \\ Pietro Di Pinto, ${ }^{2}$ Valentina Terio' \\ 'Department of Veterinary Medicine, \\ University of Bari, Valenzano; ${ }^{2} F r e e l a n c e$ \\ DVM, Bari, Italy
}

\section{Abstract}

The health and vigour of honeybee colonies are threatened by numerous parasites (such as Varroa destructor and Nosema spp.) and pathogens, including viruses, bacteria, protozoa. Among honeybee pathogens, viruses are one of the major threats to the health and wellbeing of honeybees and cause serious concern for researchers and beekeepers. To tone down the threats posed by these invasive organisms, a better understanding of bee viral infections will be of crucial importance in developing effective and environmentally benign disease control strategies. Here we summarize recent progress in the understanding of the morphology, genome organization, transmission, epidemiology and pathogenesis of eight honeybee viruses: Deformed wing virus (DWV) and Kakugo virus (KV); Sacbrood virus (SBV); Black Queen cell virus (BQCV); Acute bee paralysis virus (ABPV); Kashmir bee virus (KBV); Israeli Acute Paralysis Virus (IAPV); Chronic bee paralysis virus (CBPV). The review has been designed to provide researchers in the field with updated information about honeybee viruses and to serve as a starting point for future research.

\section{Economic and environmental value of honeybees}

The honeybee Apis mellifera is an important eusocial insect that plays a vital role in agriculture by pollinating on a wide variety of crops and flowers. (Morse and Calderone 2000; Martin, 2001; Chen et al., 2004, Teixeira et al., 2008). Although many species are known to provide pollination services, honeybees (Apis mellifera $\mathrm{L}$.) are often assumed to provide the majority of these services to agriculture (Breeze et al., 2011). It was estimated that about one third of the agricultural crops in the world depend on honeybee pollination (Gallai et al., 2009). The dependence of worldwide crops on pollinators is extremely deep and during 2005 the global economic value of insect pollination was estimated to be $\$ 212$ billion a year, which corresponds to $9.5 \%$ of the total economic value of world agriculture production for human consumption (Gallai et al., 2009).

The Honeybees offer a key ecosystem service, essential for a sustainable productive agriculture and for the maintenance of the nonagricultural ecosystem. Pollination services are mandatory for the production of crops like fruits, nuts and fibres, whereas the results of many other agricultural crops are significantly improved by pollination. A vast number of species were found to be honeybee-pollinated plants including, high bush blueberry; apple and pears; almonds; Cantaloupe; rape varieties; and others (Mayer and Lunden, 1988; Boylan-Pett et al., 1991; Reyes-Carrillo et al., 2007; Blazyte-Cereskiene et al., 2010). In a study by Sushil et al. (2013) honeybees were found to have a key role in increasing the seed production of three crops: broccoli, kohlrabi and Chinese cabbage. Apis mellifera is of great economic importance in terms of increased yield and quality of commercially grown insect pollinated and also assists self-pollinated crops in the world (Free, 1993). It has been valued that without pollinators a decrease by more than $90 \%$ of the yields of some fruit, seed and nut crops could occur (Southwick and Southwick, 1992; Crotti et al., 2013).

Since few years, concerns are rising over honeybee health and, consequently, over its impact on global economy. Honeybee populations have been in decline in North America and Europe over the last 30 years, with beekeepers routinely losing $30 \%$ of their managed colonies every winter during the last 7 years (van Engelsdorp and Meixner, 2010).

Several factors have been shown to negatively impact the longevity of honeybee colonies, including parasites (primarily Varroa mites (Sammataro et al., 2000) and Nosema microsporidia (Chen and Siede, 2007a, 2007b), pathogens (22 different viruses have been identified (Chen and Siede, 2007a, 2007b; Runckel et al., 2011), along with several bacterial and fungal brood pathogens (Aronstein and Murray, 2010; Genersch, 2008), pesticide exposure (Desneux et al., 2007), poor nutrition (Brodschneider and Crailsheim, 2010), reduced genetic diversity (Mattila and Seeley, 2007) and management practices (van Engelsdorp et al., 2012).

In 2006 a phenomenon called Colony Collapse Disorder (CCD) emerged. Beekeepers and scientists noticed that large numbers of adult honeybees were leaving their hives and failing to return, which had large implications for farmers and growers who use honeybees as pollinators. In the last years, Colony Collapse Disorder (CCD) has attracted the attention of academic and public opinion but its causes and significance remain unclear. Recent studies suggest that several
Correspondence: Valentina Terio, Department of Veterinary Medicine, University of Bari, Strada Provinciale per Casamassima Km 3, 70010 Valenzano (BA), Italy.

Tel. +39.080 .5443970 - Fax. +39.080 .5443855 .

E-mail: valentina.terio@uniba.it

Key words: Colony collapse disorder; Honeybee viruses; Infections.

Conflict of interest: the authors declare no potential conflict of interest.

Received for publication: 15 June 2015. Accepted for publication: 17 June 2015.

This work is licensed under a Creative Commons Attribution 3.0 License (by-nc 3.0).

(O)Copyright G. Tantillo et al., 2015

Licensee PAGEPress, Italy

Italian Journal of Food Safety 2015; 4:5364

doi:10.4081/ijfs.2015.5364

factors are involved in CCD, as parasites, pathogens, pesticides (and other environmental stressors) and, above all, the interactions among them (Johnson, 2010; Nazzi et al., 2012).

Considering that honeybee viruses are one of the main factors of the Colony Collapse disorder syndrome, we review recent progress in the understanding of the morphology, genome organization, transmission, epidemiology and pathogenesis of eight honeybee viruses.

\section{Colony collapse disorder syn- drome}

Colony Collapse Disorder (CCD) is characterized by a sudden loss of hives (up to $90 \%$ ) in apiaries without a clear precedent history of disease (van Engelsdorp et al., 2007, 2008; Cox-Foster et al., 2007). CCD syndrome can be differentiated from colony losses caused by other means by a rapid reduction in the adult bee population with no sign of dead bees inside the hives or in the region of the apiary (van Engelsdorp et al., 2007, 2008; Cox-Foster et al., 2007). CCD colonies often have plenty of stores (honey and pollen) and a large area of untended brood. Often the queen remains with a small group of young attending workers (van Engelsdorp et al., 2007, 2008; Cox-Foster et al., 2007). What is really strange is that the hive products are not stolen by other bees and even the wax is not spoiled by the wax moth as usually happens when an abandoned hive is left in the field. Basically both honeybees and moth seems to refuse the products of the abandoned hive. Nowadays, the cause of CCD is unknown (Cox-Foster and van Engelsdorp, 2009). It is 
likely that several stress factors, acting alone or in combination, contribute to weakening the bees and allowing opportunistic pathogens to infect and eventually kill colonies (Cox-Foster and van Engelsdorp, 2009).

Several studies implicate that the combination of Varroa destructor infestation and certain virus infections pose a serious threat to honeybee welfare (Ball, 1983; Ball and Allen, 1988; Shimanuki et al., 1994; Hung et al., 1995; Shen et al., 2005; Cox-Foster et al., 2007; Yang and Cox-Foster, 2007). In fact, the global picture identifies the honeybee parasitic mite, Varroa destructor, as the major factor in colony loss, with regions that have established mite populations, suffering consistently higher colony losses than those without. The role of the Varroa mite in colony losses is supported by a wealth of data. The mite itself contributes to weakening colony health and modifying bee behavior, but it also spreads secondary infections within and between colonies. A general consensus is emerging that this mite in association with a range of honeybee viruses is a significant factor in the losses of managed honeybee colonies seen globally. The spread of the mite $V$. destructor to the Western honeybee, and its ability to act as a viral reservoir, incubator, activator and transmitter has resulted in levels of certain viruses that affect the survival of the colony. During the last decade, honeybee virus infections have been increasingly investigated and have emerged as one of several causes of the honeybee colony losses.

In recent times, a virus called Israeli Acute Paralysis Virus (IAPV) has been considered as a marker and has been suspected (but not confirmed) to be the pathogen responsible for CCD, or at least a co-factor (Cox-Foster et al., 2007; Palacios et al., 2008). The problem of confirming this virus as a marker for CCD is its close relationship with other two viruses called Kashmir Bee Virus (KBV) and Acute Bee Paralysis Virus (ABPV) (de Miranda et al., 2010a); this similarity between these three viruses often leads to misidentification (Palacios et al., 2008). At the moment further work is required to elucidate the precise role(s) that these viruses play in this syndrome, and if they act alone in the causation of the disease or if they need external factors that can boost their virulence (Cox-Foster et al., 2007; Anderson and East, 2008; van Engelsdorp et al., 2008).

\section{Biological factors threating honeybee health}

Recent increased annual losses of honeybee colonies, partially attributed to Colony Collapse Disorder (CCD), have motivated correlative analyses of the parasitic (i.e., viruses, bacteria, fungi, mites) and environmental (i.e. chemical exposure, forage availability) threats to honeybee health (van Engelsdorp et al., 2009; Runckel et al., 2011). So, decline of honeybee colonies was attributed to several factors including pesticides, pathogens and parasites such as Nosema ceranae/Nosema apis, Crithidia mellificae, Varroa destructor, bacteria, as well as viruses (van Engelsdorp et al., 2010; Evans and Schwarz, 2011; Runckel et al., 2011).

\section{Varroa destructor}

Varroa destructor (Acari: Mesostigmata: Varroidae) is an external parasite of honeybees. Varroa dimensions are: (L) $1.1 \mathrm{~mm} \mathrm{X} \mathrm{(W)}$ $1.6 \mathrm{~mm}$ for the female and (L) $0.8 \mathrm{~mm} \mathrm{X} \mathrm{(W)}$ $0.7 \mathrm{~mm}$ for the male. The colour of the female is reddish brown, the male is greenish-white; they are crab-shaped (Morton et al., 2005). Varroa destructor is an obligate parasite that is able to attack different developmental stages and castes of honeybees and it is considered as a major pest of $A$. mellifera (Crane et al., 1978; Shen et al., 2005). The whole life cycle of Varroa is spent with their honeybee hosts. Varroa females initiate reproduction by entering the brood cells of the last developmental stage, worker or drone larvae, normally within 20-40 h before the cells are sealed (Shen et al., 2005). The mites feed upon the haemolymph of the pre-pupae, the pupae and the adults. About $60 \mathrm{~h}$ after the bee cells are capped; the adult female mite deposits her first egg and can produce over 10 progenies (Sammataro et al., 2000; Shen et al., 2005). The adult female mite and progeny feed on the haemolymph of pupae from a single feeding site (Kanbar and Engels, 2003; Shen et al., 2005). All reproduction of Varroa occurs in the brood cells, only the adult females emerge from the brood cell along with their bee host and seek another host to repeat the life cycle. Ectoparasite sucks the haemolymph from the adult and the developing pupae of honeybees, thereby reducing host vigour and immune responses, weakening the bees and shortening their life span.

Honeybee colonies infested by $V$. destructor develop the bee parasitic mite syndrome, a condition with complicated and highly variable symptoms (Shimanuki et al., 1994; Shimanuki and Knox 1997; Shen et al., 2005; Gisder et al., 2009). In spite of this symptoms variability, all infested colonies have an unusual presence of diseased brood, which is often infected with one or more honeybee viruses. Several virus disease outbreaks have been documented with the co-infestation of Varroa mites (Allen et al., 1986; Allen and Ball, 1996; Martin, 2001; Tentcheva et al., 2004). Varroa mite has been confirmed as a vector in transmitting and activating honeybee virus infections and it is well established that viruses vectored by $V$. destructor play an important role in Varroa-induced colony collapse (Ball, 1983, 1989; Ball and Allen, 1988; Hung et al., 1995; Martin, 2001; Shen et al., 2005; Sumpter and Martin, 2004; Gisder et al., 2009). These findings led to speculation that viruses and mites acting simultaneously had a synergistic negative effect on the honeybee colonies, which may underlie honeybee mortality and colony collapse (de Jong et al., 1982; Allen et al., 1986, Glinsky and Jarosz, 1992; Brodsgaard et al., 2000; Shen et al., 2005). Indeed, weakening of the bees from haemolymph loss and the possible suppression of the honeybee immune system by mite saliva during feeding may result in active viral replication. Mite saliva could contain immunosuppressive proteins that facilitate the transmission and the activation of virus infections. Although the biochemical components of mite saliva are not characterized, it is well known that tick saliva contains immunosuppressive proteins (Wikel, 1999; Shen et al., 2005). Recent works have shown that feeding by mites suppresses both the humoral and cellular immune responses of honeybees (Yang, 2004; Yang and Cox-Foster, 2005; Shen et al., 2005; Shah et al., 2009). These works have documented that Varroa mites depress honeybee immune system by decreasing the expression of immunity related genes (Shen et al., 2005). In particular, pupae parasitized by Varroa mites may suffer from an impaired immune system and seem to be more susceptible to virus infections (Yang and Cox-Foster, 2005). Although Varroa mite has been confirmed as an effective vector in transmitting and activating honeybee virus infections, the mechanism of mite-mediated transmission is uncertain. Indirect vector-borne transmission of a pathogen can occur in two ways. Mechanical transmission is an indirect vector-borne transmission process during which the pathogen is indirectly transferred from an infected host to a healthy host, without replicating in the vector. The pathogen survives briefly in a mechanical vector, which is only a carrier and it is not essential in the life cycle of the pathogen. On the other hand, in the biological vector-borne transmission the vector supports replications of the pathogen. The disease agent and the biological vector are considered to have a longstanding ecological relationship. Biological vectors are persistently infected by the pathogen and may even be a required part of that organism's life cycle. The presence of viruses in mite saliva and the accumulation of the Picorna-like virus particles in the cytoplasm, inside membrane structures, give a strong indication that the virus replicates in $V$. destructor and suggests that Varroa mite is likely a biological vector (Ongus et al., 2004; Shen et al., 2005; Chen et al., 2006a; Zhang et al., 2007). However, the molecular mecha- 
nisms, which regulate virus-vector interactions and the transmission processes, are not known in any detail. Further studies will be needed to clarify these mechanisms.

\section{Nosema spp.}

Nosema ceranae originates from Asia and was originally described as a pathogen of the Asian cavity nesting bee Apis cerana (Fries et al., 1996). It was later found to occur in colonies of Apis mellifera in Taiwan (Huang et $a l ., 2007)$ and reported from Spain (Higes et $a l ., 2006)$. It has been suggested that $N$. ceranae may be more virulent than Nosema apis when infecting $A$. mellifera, and it has been reported to cause severe colony losses, especially in southern Europe (Higes et al., 2007, 2008). $N$. ceranae has been present in the US since at least 1995 (Chen et al., 2007a, 2007b) and in Europe (Finland) since 1998 (Paxton $e t$ al., 2007). Nosema disease (nosemosis) caused by the honeybee microsporidia is one of the most important diseases in honeybees and is worldwide in distribution (Nixon, 1982). Microsporidia are possibly the smallest singlecell organisms with a true nucleus. The genus Nosema is a parasitic fungus that infects insects such as honeybees, bumble bees and silkworms. Nosema apis, which infects the Western honeybee, Apis mellifera, was first described by Zander (1909). Nosema ceranae, which attacks the Asian honeybee, Apis cerana, was reported in 1996 by Fries et al. (1996). They invade the midgut epithelial cells of the worker bees, queens and drones. Nosema has negative effects on the bee colony. It can affect the productivity and survival of honeybee colonies including adult bee longevity, queen bees, brood rearing, bee biochemistry, pollen collection and other bee behavior (Kang et al., 1976). The prevalence of Nosema has raised concerns especially with the recent declines in honeybee populations. Many of these losses have been attributed to Colony Collapse Disorder (CCD), although the specific causes of most losses are undetermined. It was reported that co-infection by virus and Nosema in honeybee might be associated with colony collapse (Bromenshenk et al., 2010).

\section{Honeybee viruses}

Among honeybee pathogens, viruses are one of the most major threats to the health and well-being of honeybees. Viruses were first identified as a new class of pathogens infecting honeybees when at the beginning of the $20^{\text {th }}$ century, a US scientist discovered that a filterable agent from diseased bee larvae could cause Sacbrood disease in the honeybee.

Till date 22 viruses have been reported to infect honeybees worldwide, primarily positive-strand RNA viruses in the families Dicistroviridae and Iflaviridae. These ones are able to infect the different developing stages of the honeybees, including eggs, larvae, pupae and adult. Although bee viruses usually persist as unapparent infections and cause no overt signs of disease, they can dramatically affect honeybee health and shorten the lives of infected bees under certain conditions.

Moreover, although usually not associated with clinical symptoms, viruses in certain cases may cause serious or lethal disease in individual bees or the collapse of entire colonies (Berenyi et al., 2006). Diseases of the honeybee may have multiple causes, such as environmental and beekeeping parameters resulting in stress and pathogenic agents which usually act simultaneously. In particular, 7 of these viruses are considered to be the cause of severe disease in honeybees threatening the world beekeeping: Acute bee paralysis virus (ABPV), Black queen cell virus (BQCV), Chronic bee paralysis virus (CBPV), Deformed wing virus (DWV), Israel acute paralysis virus of bees (IAPV), Kashmir bee virus (KBV) and Sacbrood virus (SBV).

With the exception of CBPV, which remains unassigned, the most widespread honeybee viruses have been assigned to the newly defined order Picornavirales, often referred as the Picorna-like superfamily (Baker and Schroeder, 2008). The order Picornavirales includes the Families Bacillariornaviridae, Dicistroviridae, Iflaviridae, Labyrnaviridae, Marnaviridae, Picornaviridae and Secoviridae. The Family Dicistroviridae encompasses the BQCV, assigned to the Genus Cripavirus, the unassigned Dicistroviridae ABPV and KBV, and the unclassified Dicistroviridae IAPV. The Family Iflaviridae encompasses the SBV, assigned to the Genus Iflavirus with the unclassified Iflavirus DWV, Kakugo virus (KV) and Varroa destructor virus 1 (VDV-1). All those viruses are widely distributed worldwide (Allen and Ball, 1996; Ellis and Munn, 2005; Reynaldi et al., 2010, 2011).

\section{Morphology and viral genome structures}

In general, these viruses are 30 -nm isometric particles containing a single-stranded positive RNA. Except for filamentous bee virus and Apis iridescent virus, all honeybee viruses reported so far are positive sense single stranded RNA viruses. Morphologically, these viruses, with exception of CBPV, are very similar, exhibiting isometric shaped protein capsids of approximately $20-30 \mathrm{~nm}$ in diameter, non-occluded, possessing a buoyant density in $\mathrm{CsCl}$ ranging from 1.33 to $1.42 \mathrm{~g} / \mathrm{mL}$ and a 100 $190 \mathrm{~S}$ sedimentation coefficient (Bailey et al., 1976; Chen et al., 2005b; Baker and Schroeder, 2008). Because of their similar morphological characteristics, it is particularly difficult to distinguish by electron microscope analysis; moreover it is a common phenomenon that several viruses of similar size and shape coexist in natural populations of honeybees (Anderson and Gibbs, 1988; Chen et al., 2004). The outer shell of the capsid is composed of 60 repeated protomers, each one consisting of a single molecule of 3 subunits VP1, VP2, VP3. In addition there is a smaller fourth protein VP4 that is present in the viral particle of some viruses such as BQCV and ABPV (Govan et al., 2000; Leat et al., 2000). VP4 is not exposed at the surface of the virions and is located on the internal surface of the fivefold axis below VP1. The capsid proteins play an important role in the protection of viral RNA from activities of RNase, in the protection of adverse environmental factors and in the determination of viral host specificity and tissue tropism.

With the exception of CBPV, honeybee viruses also share similarities within their genome sequences, particularly within the helicase, protease and polymerase domains of the replicase polyprotein and also with the order of these 3 domains (Baker and Schroeder, 2008). The viral genome is composed of a single stranded RNA molecule coated with capsid proteins. The size of the genome of honeybee viruses ranges from 8550 to $10140 \mathrm{bp}$, excluding the polyA tail at the 3 ' end. The length of the polyA tail is genetically determined and varies in different viruses. The RNA genome is covalently attached by a small protein called VPg (viral protein genome linked) at the 5 ' and by a polyA tail at the 3 ' ends. VPg are important to stabilize the 5' end of the RNA genome and serves as a primer for replication and translation. At the 5' end, there is a long untranslated region (UTR) containing a clover-leaf secondary structure, assumed to be involved in initiation of translation. To date, the complete genome sequences of SBV (Ghosh et al., 1999), KBV (de Miranda et al., 2004), ABPV (Govan et al., 2000), BQCV (Leat et al., 2000), DWV (Lanzi et al., 2006), IAPV (Maori et al., 2007a) and CBPV (Olivier et al., 2008a) have been reported.

RNA-dependent RNA polymerase (RdRp) was validated as a good marker for studies concerning RNA virus classification and evolution (Baker and Schroeder, 2008). Previous research has identified 8 conserved domains within the RdRp gene of the positive sense single stranded RNA viruses (Baker and Schroeder, 2008). The genome organization of $\mathrm{ABPV}, \mathrm{BQCV}$, and KBV is typical for the Dicistroviridae and consists of two non-overlapping open reading frames (ORF), separated 
by an intergenic region (IGR) and flanked by untranslated regions (UTR). The genome of these viruses is monopartite bicistronic, with the larger ORF located in the 5' half of the genome and encodes the non-structural proteins involved in virus replication and processing. The shorter ORF is located towards the 3' end of the genome and encodes the structural proteins found in the viral particle (Govan et al., 2000; de Miranda et al., 2004, 2010a; Maori et al., 2007a).

The genome organization of the viruses assigned to the Genus Iflavirus consists of a single ORF flanked by a long 5' UTR and a short, highly conserved, 3' UTR. Both UTRs are involved in the regulation of the replication and translation of the genome (de Miranda and Genersch, 2010b). The genome of SBV and DWV is monopartite monocistronic with the structural proteins encoded in the 5' proximal ORF and the non-structural proteins encoded in the 3' proximal ORF.

Up to now, CBPV is not included in any Family or Genus. Indeed this virus is characterized by different physical-chemical properties, particle symmetry and size, and distinctive genome composition and organization (Ribière et al., 2010). Morphologically CBPV exhibits an anisometric structure, mostly ellipsoidal particles, of approximately $30-65 \mathrm{~nm}$ in modal length and about $20 \mathrm{~nm}$ in width (Bailey et al., 1968; Ribière et al., 2010). This structure of viral particles is an exception among honeybee viruses and it is unusual in non-enveloped viruses (Ribière et al., 2010). The CBPV genome contains 5 single stranded RNA fragments (RNAs): 2 major RNAs, RNA 1 and RNA 2 of about 3674 nt for RNA 1 and 2305 nt for RNA 2, and 3 minor RNAs, RNA 3a, RNA 3b, RNA 3c, each one of about 1100 nt (Overton et al., 1982; Fauquet et al., 2005; Ribière et al., 2010). The analysis of CBPV sequences has showed that RNA 1 and RNA 2 encode 3 and 4 putative overlapping ORFs respectively (Olivier et al., 2008a; Ribière et al., 2010). The ORF 3 on RNA 1 shows significant similarity with viral RdRp, and especially with the conserved sequence domains of the RdRp of single strand RNA viruses. The sequence encompassing the 8 conserved domains of the RdRp, have showed a very low similarity percentage between the CBPV sequence and those members of the Dicistroviridae Family. Instead, CBPV shares several characteristics with viruses in the Nodaviridae and Tomboviridae Families (Ribière et al., 2010). Although this similarity, CBPV differs from 2 previously cited Families according to the various demarcation criteria defined by the International Committee on Taxonomy of Viruses (ICTV). Therefore CBPV should be considered as the prototype species of a new group of positive strand RNA viruses.

\section{Routes of transmission}

The worldwide diffusion of these viruses is promoted to less knowledge of viral infections in honeybees, in particular referred to different ways of transmission, to the pathogenesis of honeybee viruses and to their interactions with the host.

Honeybees live in colonies consisting of two generations: one mother queen and her successors. Individual bees in the colony work together in a highly structured social order and engage in numerous coordinating activities. Because of densely crowded populations and high contact rate between colony members related to feeding and chemical communication, honeybee colonies provide great opportunities for pathogen transmission.

A most crucial stage in the dynamics of viral infections and in the evolutions of hostpathogen interactions is the way of transmission. Transmission processes determine the spread and the persistence of pathogens in a population. In general, transmission of viruses can occur through two pathways: horizontal and vertical transmission.

In horizontal transmission, viruses are transmitted among different individuals of the same generation. In vertical transmission, viruses are passed vertically from mother to offspring via eggs, either on the surface of the eggs (trans ovum transmission) or within the eggs (trans ovarian transmission) (Chen et al., 2006a).

Horizontal transmission can be further classified as direct or indirect. In direct horizontal transmission the virus passes directly from an infected organism to a healthy one. Horizontal transmission by a direct route includes airborne infection, foodborne infection and venereal infection. Transmission by an indirect route involves a biological or physical vector which acquires and transmits virus from one host to another one.

Because of high population density, high physical contact rates and high trophallaxis rates, direct foodborne and oro-fecal transmission are significant routes for spreading diseases. Several works have demonstrated the presence of high titre virus in food resources, gut and faeces (Bailey et al., 1964; Hung, 2000; Shen et al., 2005a; Chen et al., 2006a; Ribiere et al., 2007; de Miranda and Fries, 2008). In 2006a Chen et al. have conducted a study to investigate the presence of viruses in the gut of queens and have proved the presence of DWV and BQCV in the gut tissue. Quantification of viruses in different tissues has indicated that virus titre detected in gut has been significantly higher than other examined tissues including haemolymph, ovaries, head, spermatheca and eviscerated body (Chen et al., 2006a). These results give greater statistical significance of foodborne transmission than other ways of transmission.

The detection of viral genomic sequences in the reproductive organs of both queens and drones, and in the extracted semen (Chen et al., 2004, 2005b, 2006b; Fievet et al., 2006; Yue et al., 2006, 2007; de Miranda and Fries, 2008), suggests the existence of venereal transmission in honeybees. In 2008 Miranda and Fries have demonstrated venereal transmission of DWV through artificial insemination with infected semen in DWV-free virgin queens (de Miranda and Fries, 2008). Genomic sequences of DWV were detected not only in the spermatheca, but also in ovaries. These results have demonstrated the existence of DWV venereal transmission by artificial insemination. The epidemiological significance of venereal and subsequent vertical transmission may be considerable, despite the lower virus titres in the reproductive organs than digestive organs (de Miranda and Fries, 2008). Indeed, after the insemination, the return of the queens to their colonies is followed by the release of a small amount of sperm at time to fertilize their eggs, ensuring a further spread of the virus through vertical transmission of DWV (Yue et al., 2007; de Miranda and Fries, 2008). Natural mating takes place in drone congregation areas where the drones and queens from many different colonies meet (Baudry et al., 1998; de Miranda and Fries, 2008). Each queen mates with up to 20 drones (Estoup et al., 1994; de Miranda and Fries, 2008), this is a great opportunity for the virus transmission from a colony to another one. Fortunately, natural mated queens benefit from the exhaustive mating flight, which selects against genetically or physiologically impaired drones. Mating flight presents an effective barrier to virus venereal transmission. On the contrary, the semen collected for artificial insemination must be analysed with specific bio-molecular test for the detection of viruses.

Vertical transmission of viruses occurs in mammals, vertebrates, arthropods and plants. Several works have documented this transmission pathway in honeybees (Chen et al., 2005, 2006b; Shen et al., 2005; Yue et al., 2007; de Miranda and Fries, 2008). Vertical transmission can be realized in 2 ways, either through fertilisation of the eggs with contaminated semen, or through ovarian tissues of queens infected before oviposition. In the first instance only fertilised eggs (worker) will be infected, whereas in the second one both worker and drone progeny will be infected. In 2008 Miranda and Fries have detected that only 2 of 3 queens inseminated with DWV contaminated semen developed infection in their ovaries and spermatheca. The two infected queens still produced about 30\% DWV free progeny, across several progeny classes (eggs, larvae, pre-pupae and pupae). These observa- 
tions are confirmed to other works that have documented a great variation in vertical transmission efficiency among infected queens (Yue et al., 2006, 2007; de Miranda and Fries, 2008). Therefore, the huge knowledge of the mechanisms that can modulate the efficiency of venereal and vertical transmission is very important to control the spread of these diseases.

Another way of virus transmission is vectorborne transmission (indirect route of horizontal infection) that involves a physical or biological vector. This vector acquires and transmits viruses from infected host to healthy one. The detection of several bee viruses in Varroa mites indicates the possible role of these ectoparasites as vectors in the transmission of viruses among honeybees (Ongus et al., 2004; Tentcheva et al., 2004; Shen 2005b; Yue and Genersh, 2005; Chantawannakul et al., 2006; Fujiyuki et al., 2006; Zhang et al., 2007; Shah et al., 2009).

The different transmission ways play a crucial role in determining the virulence of a pathogen. Evolution of virulence is governed by competition between horizontal and vertical modes of transmission (Clayton and Tompkins, 1994; Ewald, 1994; Chen et al., 2006). Horizontal transmission is strongly dependent on the production of high numbers of pathogens causing an increased virulence. This transmission way is characterized by a higher rate of multiplication, bringing about heavy host exploitation. On the contrary, vertically transmitted pathogens are directly dependent upon the survival and the reproduction of their hosts. Vertical transmission plays an important role in the long-term maintenance of viruses in the wild. Any reduction in host survival and in reproduction ability will cause the decrease of the pathogen transmission. Vertical transmission is associated with a low virulence, which is a characteristic of a latent infection. In case of pathogen replication is too low, the pathogen will lose opportunities to infect new host. If the replication rate of pathogens is too high, the strong virulence will result in high pathogen-induced host mortality, and the hosts will die before producing enough pathogens to infect more hosts. Therefore, a pathogen's fitness is determined by a conflict in the selective pressures between horizontal and vertical modes of transmission. Both transmission pathways are important survival strategies for viruses not only for their persistence in bee population but also for their establishment in nature (Clayton and Tompkins, 1994; Ewald, 1994; Chen et al., 2006). Viruses choose the appropriate transmission pathway based on the physiological and ecological conditions. When colonies are under healthy conditions, viruses persist through vertical transmission in latent infections without causing any overt symptoms.
Instead, when honeybees are under stressful conditions such as co-infection of other pathogens or decline of food resources, viruses switch to horizontal transmission. The high numbers of produced viral particles result in the death of hosts and the possible collapse of the whole bee colony. The mechanisms by which viruses could be reactivated in honeybees are not fully understood.

\section{Deformed wings virus and Kakugo virus}

Deformed wing virus (DWV) was first isolated in Japanese apiaries from adult honeybees with a particular deformity of wings (Bailey and Ball, 1991). DWV is one of the larger widely distributed honeybee viruses around the globe. Except for Oceania, the infection of DWV has been reported in Africa, Asia, Europe, North America and South America (Allen and Ball, 1996). Several studies have showed that DWV infection in A. mellifera is characterized by a bigger prevalence than other honeybee viruses without any kind of geographic limitation. In France $97 \%$ of beehives have adult bees infected by DWV and in $100 \%$ of beehives infested by $\mathrm{V}$. destructor, with the detection of the virus even in the mite (Tentcheva et al., 2004). Tentcheva et al. (2006) have demonstrated the higher prevalence of DWV infections in pupae then adult bees and that the frequency of DWV infections increased from spring to autumn. These seasonal variations in DWV incidence were much more pronounced for pupae than for adult bees. These results are probably due to the minor efficiency of immune system of pupae than adult bees. Other authors (Sanpa and Chantawannakul, 2009) have observed that even in Thai beehives the DWV was present most frequently than other honeybee viruses, confirming that DWV prevalence in the pupae was bigger than in the adult bees (Sanpa and Chantawannakul, 2009). This research is deeply important because it has highlighted the presence of DWV also in apiaries free from V. destructor, showing the possibility of other honeybee virus routes apart from mites, such as Tropilaelaps mercedesae, another hemolimphfeeding ectoparasite (Dainat et al., 2009, Forsgren et al., 2009; de Miranda and Genersch, 2010b).

The DWV is present also in South America where a particular hybrid of Apis mellifera of African origin, called Africanized honeybees (AHBs), is bred (Teixeira et al., 2008). The high level of resistance towards mites and other pathogens promoted the diffusion of AHBs (Aumeier, 2001; Teixeira et al., 2008). In Brazilian beehives the DWV infection showed its pathogen activity exclusively in colonies heavily infested by $V$. destructor (Teixeira et al., 2008).

DWV is a virus with a low pathogenicity and often it is responsible for latent infections that can appear after a stressful situation such as high infestation of $V$. destructor, lack of alimentary resource or wrong beekeeping management. DWV is able to infect all bee developmental stages from eggs to adults, even if it shows a higher replication in pupae (Chen $e t$ al., 2005a, 2006b; Yue and Genersh 2009; Sanpa and Chantawannakul, 2009; de Miranda and Genersch, 2010). The persistence of DWV is guaranteed by the low pathogenicity of DWV. Indeed, it multiplies slowly in its hosts, without causing their death. The pupae can complete their life cycle evolving in asymptomatic or symptomatic adult bees, it depends on the presence or the absence of stressful factor in the colony. Both asymptomatic and symptomatic honeybees have a sensible reduction in their life span (Kovac and Crailsheim, 1988; Bailey and Ball, 1991). DVW is one of a few bee viruses that cause well-defined disease symptoms. DWV characteristic symptoms include shrunken wings that make impossible the flight, decreased body size and discoloration in adult bees. The mechanism by which the DVW causes this kind of symptoms in the stressful hosts is not yet clear. Anyway the typical symptoms of DVW infection are often detected in apiaries infested by V. destructor (Tentcheva et al., 2004). The mite is responsible of the DWV spreading in all bee tissues by haemolimph spoliation and reactivation of viral infections (Fievet et al., 2006). Several works have detected honeybee colonies with co-infections by DWV and other honeybee viruses (Teixeira et al., 2008; Sanpa and Chantawannakul, 2009). In healthy colonies, these co-infections are not associated with acclaimed symptoms.

Previous studies have demonstrated the presence of DWV in stools of adult bees (Chen et al., 2006), in the glandular secretions of nurse bees (Fievet et al., 2006), in the semen of apparently healthy drones (Fievet et al., 2006; Yue et al., 2006) and in the spermateca, ovaries and eggs of infected queen bees (Fievet et al., 2006; Yue et al., 2007). These data confirm the hypothesis of vertical transmission and horizontal transmission through the alimentary and the venereal routes.

In 2004 a novel unclassified Iflavirus was isolated for the first time in Japan from the brains of aggressive worker honeybees (Fujiyuki et al., 2004). This new RNA virus was termed Kakugo virus (KV) which means ready to attack in Japanese. This virus shows a great homology with DWV, 98\% at the nucleotide level (Terio et al., 2008). There are approximately 201 nucleotide substitutions, deletions or insertions which are characteristic to KV, 21 of them determines amino acid substitutions in the polyprotein and 7 of them are located in 
the conserved domain structures (Fujiyuki et al., 2004). These small variations are sufficient to modify the tissue tropism of KV. Moreover the genome of these 2 viruses show a higher polymorphism in the putative leader polyprotein coding region which has already been found to be associated with viral pathogenesis (Rortais et al., 2006).

The specific target of $\mathrm{KV}$ is the brain of honeybees, in particular high concentration of genomic RNA have been detected in the optic and antennal neuropilis in the honeybee brain and in mushroom bodies (Rortais et al., 2006; Shah et al., 2009). The virus is present in the brain regions that process the honeybee sensory experiences and coordinate the behaviour. No wing deformities have been associated with this virus, however, these different symptoms, the aggressive behaviour and the wing deformities, need not be mutually exclusive (Lanzi et al., 2006; Iqbal and Mueller, 2007; de Miranda and Genersch, 2010). KV was detected specifically from aggressive workers in some colonies, although it was detected from other worker populations in other colonies. In KV-infected colonies parasitized by Varroa destructor, the sequences of $\mathrm{KV}$ have also been found in the mites, suggesting that the mites mediate KV diffusion in the honeybee colonies (Chen et al., 2006). In 2006 Fujiyuki et al. have detected KV not only in the brains, but also in the heads without brains, thoraxes and abdomens of the reserve bees. These data can be determined by different physiological conditions of honeybees that modify the tissue distribution of $\mathrm{KV}$, supporting the argument advanced by some authors, according to which it is possible that $\mathrm{KV}$ and DWV represent a regional variants of the same virus. Artificial infection experiments using infectious clones of these viruses will be needed to test these possibilities.

\section{Sacbrood virus}

Sacbrood virus (SBV) caused the most widely distributed honeybee virus infection detected for the first time in 1913 in the USA (White, 1913). This virus can infect either larvae or adult honeybees, with a higher sensibility of larvae to the infection. Indeed SBV primarily affects the brood of the honeybees with a high viral replication that causes significant morphological alterations resulting in larval death (Berenyi et al., 2006). Infected larvae fail to pupate and ecdysial fluid, rich in SBV particles, accumulates beneath their undigested integument forming the sac for which the disease is named. The infected larvae change their colour from pearly white to pale yellow and immediately after death they dry out forming a dark brown ship-shaped scale (Grabensteiner et al., 2001). The adult bees develop a latent infection characterized only of a decreased life span, without acclaimed symptoms (Grabensteiner et al., 2001; Berenyi et al., 2006). This latent infection is very important for the diffusion of the SBV because this virus is accumulated in the head and especially in the hypopharyngeal glands of infected nurse bees, which are responsible for feeding the larvae through their infected glandular secretion (Shen et al., 2005). Moreover the adult bees detect and remove larvae killed by SBV, a day or two day after the die while the virus is still infectious (Bailey et al., 1964; Shen et al., 2005). These data suggest that SBV is probably transmitted to the adults by the ingestion of dead larva parts, especially ecdysial fluid.

The detection of SBV in pollen (Shen et al., 2005) confirms the possible transmission of the virus from workers to other adult bees via food resources in the colony. It is also possible that SBV might be transmitted among colonies by feeding the bees through the honey or pollen gathered from diseased colonies. This practice is used by some bee-keepers to help the colonies to survive during periods of low flowering (Shen et al., 2005).

SBV infection was detected in large amount of adult bees from apiaries infested by $\mathrm{V}$. destructor (Ball, 1989; Antunez et al., 2006; Bereneyi et al., 2006). The high levels of virus detected in the ectoparasite especially in mouth parts and digestive tracts (Tentcheva et al., 2004; Shen et al., 2005; Chantawannakul et $a l ., 2006)$ and the positive correlation between the prevalence of SBV in mite samples and the presence of SBV in adult bee samples (Tentcheva et al., 2004), allow us to hypothesize a possible role of Varroa as a vector of this infection. Further studies to elucidate the role of Varroa mite as physical or biological vector in SBV transmission will be necessary.

The frequencies of SBV infection were much higher during the spring, when the brood seasons begins and large numbers of susceptible larvae and young adults are available (Anderson and Gibbs, 1988; Grabensteiner et al., 2001; Tentcheva et al., 2004; Bereneyi et al., 2006). Indeed during this season the rich sources of pollen and nectar stimulate brood rearing. The seasonal variation of SBV infection observed both in adult bees and pupae also might reflect a change in the environment, such as the quality of pollen.

\section{Black Queen cell virus}

Black Queen cell virus (BQCV) was originally isolated from dead queen larvae and pupae sealed in their cells (Bailey and Woods, 1974; Leat et al., 2000) and has proved to be the most common cause of death of queen larvae in
Australia (Benjeddou et al., 2001). The BQCV infection has been detected also in America, Europe, Asia, Africa and the Middle East (Allen and Ball, 1996, Ellis and Munn, 2005). Within infected colonies BQCV is more prevalent in adult bees than pupae (Tentcheva et al., 2004), although it clinically affects mainly developing queen larvae and pupae of the queen, which constitute the primary hosts of the virus. These larvae acquire a pale yellow appearance and a tough sac-like skin, similarly to symptoms caused by SBV infection. The name of the virus was derived from darkened areas on the walls of cells containing infected pupae; within died pupae are collected a large number of viral particles (Bailey and Woods, 1974; Leat $e t$ al., 2000).

Studies of experimental infections have documented that this virus multiplies readily when injected into the pupae (Bailey and Woods, 1974; Leat et al., 2000). Nevertheless this virus is able to multiply in adult bees if ingested with spores of the microsporidian parasite Nosema apis (Bailey et al., 1983; Leat et al., 2000; Tentcheva et al., 2004). It infects mid-gut tissue of the adult bees, increasing the susceptibility of this district to BQCV infection. Indeed, an important correlation was observed between the incidence of BQCV and Nosema apis in honeybee colonies with a peak of infection/infestation during spring and early summer (Bailey et al., 1983; Allen and Ball, 1996; Leat et al., 2000; Benjeddou et al., 2001). These data suggests that BQCV may be implicated in the mortality of bees infested with this parasite.

BQCV is able to propagate in apparently healthy white-to purple-eyed drones or worker bee pupae (Benjeddou et al., 2001). The detection of BQCV sequences in queen faeces and in tissues of the gut (Chen et al., 2006a, 2006b) proves the food-borne transmission of this virus, suggesting a possible infection of queen brood through glandular secretions of infected nurse bees during the feeding (Bailey et al., 1982). To date, there are conflicting data concerning the role of $\mathrm{V}$. destructor in this infection. To exception of Varroa mite samples collected from Thai apiaries (Chantawannakul et al., 2006), this honeybee virus was never detected in any mite samples. Further studies will be needed to clarify the role of Varroa mites as a vector of BQCV infection.

\section{Acute bee paralysis virus}

Acute bee paralysis virus (ABPV) was originally discovered during laboratory experiments as a cause of asymptomatic infections of adult bees (Benjeddou et al., 2001). This virus is a common infective agent of honeybees, frequently detected in apparently healthy colonies 
from several countries worldwide (Allen and Ball, 1996; Békési et al., 1999; Benjeddou et al., 2001; Farkas et al., 2001; Bakonyi et al., 2002a, 2002b; Tentcheva et al., 2004; Antúnez et al., 2005; Ellis and Munn, 2005; Berényi et al., 2006; Forgach et al., 2007; Sanpa and Chantawannakul, 2009). These infections are sometimes exacerbated and activated by stressful environmental factors such as mite infestations, bacterial infections, pollution and the usual utilization of chemicals and insecticides in agricultural technology (Bakonyi et al., 2002a, 2002b). The overt infection of ABPV is characterized by rapid death of adults; previously the lethally infected adults show a rapidly progressing paralysis, including trembling, inability to fly and the gradual darkening and loss of hair from the thorax and abdomen (Bailey et al., 1963; Maori et al., 2007a; Ribière et al., 2008; de Miranda et al., 2010a).

ABPV could attack all stages of honeybees, but the most favourable hosts for virus multiplication were the pupae (Chen et al., 2005a; Sanpa and Chantawannakul, 2009). Either the accumulation of viral particles in the brain and especially in the hypopharyngeal glands (de Miranda et al., 2010) and the readily detection of ABPV in the faeces (Hung, 2000; Ribière $e t$ al., 2008; de Miranda et al., 2010a), prove the foodborne transmission of virus through the salivary gland secretions of infected adult bees used to feed the young larvae or mixed in the pollen (Benjeddou et al., 2001). Infected larvae either die before they are sealed in brood cells if large amounts of virus particles were ingested, or survive to emerge as healthy infected adult bees (Bailey and Ball, 1991). The detection of ABPV sequences in semen of apparently healthy drones (Yue et al., 2006) suggests the possibility of venereal transmission of this virus. Further studies will be necessary to clarify this crucial aspect and to analyse the impact of the consequent vertical transmission of the virus through the eggs.

$\mathrm{ABPV}$ has been indicated as the major factor contributing to the mortality of honeybees infested with V. destructor (Faucon, 1992; Nordstrom, 2000; Bakonyi et al., 2002a, 2002b; Antúnez et al., 2005) and it was detected to be a primary cause of mortality in weakened colonies from Germany, Yugoslavia, France, Hungary (Forgàch et al., 2007) and USA (Bakonyi et al., 2002a, 2002b). Moreover several studies have also detected the presence of ABPV in Varroa mites (Allen et al., 1986; Bakonyi et al., 2002a, 2002b; Tentcheva et al., 2004; Chantawannakul et al., 2006). The term bee parasitic mite syndrome has been used for the disease complex observed in infested colonies simultaneously infected by viruses, characterized by high mortality (Shimanuky $e t$ al., 1994; Hung et al., 1995). Due to the spread of the Varroa mite in the European apiaries during the last decade, ABPV has gained rele- vance (Berènyi et al., 2006). Indeed, the parasitic mite plays a crucial role in spreading this virus both as a vector and as an activator of viral infection weakening the honeybees (Bakonyi et al., 2002a, 2002b; Berènyi et al., 2006).

\section{Kashmir bee virus}

This virus is widely diffused in Australia and in the United States, where it is endemic, it has been reported in Europe only rarely (Tentcheva et al., 2004; Berènyi et al., 2006). Like most dicistroviruses (Christian and Scotti, 1998; Valles et al., 2007; de Miranda et al., 2010), KBV persists at low titres in apparently healthy colonies until several stress factors activate the viral multiplication causing the death of the colony. The KBV overt infection occurs in different developing stages of bees without clearly defined disease symptoms. In last decade, this potentially lethal virus is becoming more important as one of several viruses closely associated with colony collapse in apiaries infested by V. destructor (Hung et al., 1995, 1996c; Ball and Bailey, 1997; de Miranda et al., 2004; Todd et al., 2007; Ribière et al., 2008; Pettis et al., 2008; de Miranda et al., 2010a, 2010b).

$\mathrm{KBV}$ is genetically and serologically closely related to ABPV (Allen and Ball, 1996; de Miranda et al., 2004); both these viruses were discovered as a contaminant during transmission studies of CBPV (Bailey et al., 1963; de Miranda et al., 2004). Probably these two viruses originate from a common ancestor and evolved independently in secluded geographic regions (Berènyi et al., 2006). Both viruses are able to co-infect the same colony (Hung et al., 1996; de Miranda et al., 2004) and even within the same bee (Evans, 2001; de Miranda et al., 2004). Although these two viruses are closely related they are readily distinguished by RTPCR (Stoltz et al., 1995; Evans, 2001; de Miranda et al., 2004), moreover the VP4 proteins of ABPV and KBV particles are serologically distinct (Stoltz et al., 1995; de Miranda et al., 2004). Indeed, between these two viruses there are significant differences concerning critical areas of the genome such as the 5' NTR (de Miranda et al., 2004). This region contains primary and secondary RNA structures that are fundamental for the binding of the viral RNA polymerase for genome replication (Gromeier et al., 1999).

In experimental infections $\mathrm{KBV}$ is resulted extremely lethal to adults and larvae, (Bailey $e t$ al., 1963; Dall, 1985; Bailey and Ball, 1991; Ribière et al., 2008; de Miranda et al., 2010a, $2010 \mathrm{~b}$ ), with less than 100 particles required to cause death within a few days, and the same effect can also be achieved by feeding around
1011 virus particles per bee (Bailey et al., 1963; Bailey and Woods, 1974; Bailey and Ball, 1991; Nordström, 2000; Maori et al., 2007a; Ribière et al., 2008; de Miranda et al., 2010a, 2010b). In natural infections KBV affects all stages of the bee life cycle and commonly persists within brood and adults apparently healthy (Anderson and Gibbs, 1988; Dall, 1985; de Miranda et al., 2004, 2010a, 2010b). The transmission of KBV in natural infected colonies may be occurred through multiple routes (Shen et al., 2005). The detection of KBV in brood food, honey, pollen royal jelly and faeces confirm the oral transmission of infection via contaminated food resources in the colony (Shen et al., 2005; Chen et al., 2006a; Chen and Siede, 2007a, 2007b; de Miranda et al., 2010a, 2010b). The detection of viral genome in Varroa mites and their salivary secretions (Shen et al., 2005; Hung and Shimanuki, 1999; Hung, 2000) suggests that the parasite may act as vector of KBV even if further studies will be needed to clarify the effective role of Varroa as biological or physical vector.

In recent years the virus has proved to be a most important marker of Colony Collapse Disorder (CCD) (Pettis, 2008; de Miranda et al., 2010a, 2010b). CCD is characterized by rapid loss of the colony's adult bee population. At the final stages of collapse, the queen is attended by only a few newly emerged adult bees (Pettis et al., 2007; Maori et al., 2009). CCD poses a serious threat to apiculture and agriculture worldwide and CCD-related losses (direct and indirect) have been estimated at $\$ 75$ billion (Swinton et al., 2007; Maori et al., 2009). Further work is, therefore, required to elucidate the precise role of KBV plays in this syndrome and the possible existence of other environmental and biological factors that could be able to play an important role in the spread of CCD.

\section{Israeli acute paralysis virus}

The Israeli Acute Paralysis Virus (IAPV) was first isolated in 2004 from Israeli apiaries, where it caused a significant mortality in honeybees inflicting heavy losses on Israeli apiculture (Maori et al., 2007a, 2007b; Blanchard et $a l ., 2008)$. The sequence analysis of this virus have indicated that IAPV is a new member of Dicistroviridae family (Maori et al., 2007a; Blanchard et al., 2008), closely related to KBV and ABPV. Apart their close genetic relationship, they several biological characteristics, such as the primary host life stage and a low but widespread prevalence in asymptomatic infections that contrasts with the high virulence in experimental infections (de Miranda et al., 2010). Despite the high homology between these three viruses, the ABPV is char- 
acterized by significant genetic and serological differences (Maori et al., 2007; Blanchard et al., 2008).

Besides Israel, the ABPV is widespread in Australia and in several U.S. states such as Florida, California, Maryland and Pennsylvania (Chen and Evans, 2006a; Cox-Foster et al., 2007; Maori et al., 2007a, 2007b; Blanchard et al., 2008; Palacios et al., 2008; de Miranda et al., 2010a). In natural infected colonies ABPV persists at low titres without overt symptoms. The intervention of several stress factors due to a weakening of the honeybee defences that leads to death of the honeybees. The death of lethally infected adults is preceded by a rapidly progressing paralysis, including trembling, inability to fly and the gradual darkening and loss of hair from the thorax and abdomen (Bailey et al., 1963; Maori et al., 2007a; Ribière et al., 2008; de Miranda et al., 2010a). Due to the recent identification of this virus, there are still gaps in knowledge about the transmission routes of IAPV. Further studies will be needed to clarify these crucial aspects of the IAPV infection.

\section{Chronic bee paralysis virus}

Chronic bee paralysis virus (CBPV) is a common single-stranded RNA virus which may cause significant losses in honeybee colonies. It was first isolated in 1963 from diseased honeybees (Bailey et al., 1963; Olivier et al., 2008a, 2008b). CBPV has been directly detected by serological methods in dead adult bees from every continent (Ribière et al., 2010) except South America, where it has been detected by molecular techniques (Antúnez et al., 2005; Blanchard et al., 2007; Ribière et al., 2010). The prevalence of this infection did not appear to follow any seasonal pattern (Tentcheva et al., 2004).

This virus can persist through the years as a covert infection but may multiply to high levels in honeybees (Blanchard et al., 2007; Ribière et al., 2007; Olivier et al., 2008) and may cause an overt infection with significant losses in colonies (Allen and Ball, 1996; Olivier et al., 2008a, 2008b). Scarcity of food resources, severe winters or adverse weather conditions in summer may promote these outbreaks (Allen and Ball, 1996; Bailey et al., 1983; Olivier et al., 2008a, 2008b). In these overt infections CBPV was identified as a cause of a contagious disease of adult honeybees characterized by trembling, flightless and sometimes black individuals crawling at the hive entrance (Bailey et al., 1963; Allen and Ball, 1996; Chen et al., 2005; Ribière et al., 2007).

The CBPV overt infection is characterized by two different syndromes that can bees seen even in honeybees from the same colony
(Bailey and Ball, 1991; Ribière et al., 2010). The most common one is characterized by abnormal trembling of the body and wings, bloated abdomens and partially-spread dislocated wings that causing an inability to flight. The bloated abdomen is caused by distension of the honey sac with fluid which accelerates the onset of dysentery. The affected honeybees die within a few days following the onset of symptoms (Ribière et al., 2007). The other syndrome is characterized by hairless, shiny and black appearing bees which makes them seem smaller than healthy bees, with a relatively broader abdomen. Because of their different appearance, the affected bees suffer nibbling attacks by healthy guard bees of their colony, which makes them, seem like robber bees. In a few days they become flightless, trembling, and soon die.

The CBPV paralysis appears to be due to the neurotopism of the virus, indeed the fifty percent of the many millions of CBPV particles which can be extracted from only one paralysed bee is concentrated in the head, which represents about one-tenth of the total body weight (Ball, 1999; Olivier et al., 2008a, 2008b). CBPV particles were observed in the neurons of the higher integration centres: the mushroom bodies and the central complex (Olivier et al., 2008a, 2008b). The mushroom bodies are involved in sensory processing, learning, memory storage and the control of motor patterns like walking (Menzel, 2001; Heisenberg, 2003; Olivier et al., 2008a, 2008b). The central complex is involved in higher locomotor control, orientation behaviour and regulation of arousal of the insect (Schildberger, 1983; Strauss, 2002; Wessnitzer and Webb, 2006; Olivier et al., 2008a, 2008b). CBPV particles have been seen in sections of brain tissue, hypopharyngeal and mandibular ganglia and in abdominal and thoracic ganglia (Giauffret $e t$ al., 1966; Olivier et al., 2008a, 2008b).

Laboratory experiments have proved that CBPV can be easily transmitted to bees by topical application to the surface of cuticle freshly denuded of its hairs (Ribière et al., 2007). Moreover, the crowded condition of the colonies promotes the spread of the virus by direct contact of healthy bees with paralysed individuals (Ribière et al., 2007). The systematic detection of CBPV particles in faeces of both naturally and experimentally infected bees with acclaimed symptoms proves an important source of environmental contamination in the colony (Ribière et al., 2007). Further studies will be necessary to clarify the resistance of the viral particles outside the host and its ability to infect healthy individuals confined in contaminated apiaries. The detection of CBPV in queens (Chen et al., 2005a, 2005b, 2006b; Ribière et al., 2010) and in all developmental stages of their offspring including eggs has been reported (Chen et al., 2006b;
Blanchard et al., 2007; Ribière et al., 2010), suggests the possibility of vertical transmission of this virus. CBPV infections have never been related to Varroa destructor infestations and the virus has not been reported in this parasite (Ribière et al., 2007).

\section{Conclusions}

The long-term decline of honeybee hives in the USA and European countries has become an issue of widespread interest and concern. Based on many studies aimed at identifying all the putative factors afflicting honeybees, evidence is accumulating that one of the major causes of colony losses is the occurrence of viruses and their association with an invading parasites, $V$. destructor and Nosema spp.

Nowadays there is no doubt that the impact of various syndromes implying bee viruses is a global threat for apiculture. Possible treatments against virus infections in honeybees have never been seriously considered before. Various approaches for combating bee viral diseases are described: they include selection of tolerant bees, RNA interference and prevention of new pathogen introduction. None of these approaches are expected to lead to enhanced bee-health in the short term. Therefore, the deep knowledge of crucial aspects in the dynamics of viral infections and, in particular, the different ways of transmission and the different activation factors of asymptomatic infections, such as co-infections with bacteria or parasites and the effect of chemicals released into the environment or dietary deficiencies (Tentcheva et al., 2004) are very important to realize an efficacious disease control program. Moreover, diagnosis of bee virus infections is difficult because honeybee viruses usually persist as unapparent infections and cause no overt signs of disease. In addition, attempts to determine the frequency of viruses in the field have been slowed by the fact that more than one virus can attack bee colonies. Multiple viral infections have been reported in bees by a number of authors including Anderson and Gibbs (1988), Benjeddou et al. (2001), Evans (2001), Hung et al. (1996a, 1996b), and Leat et al. (2000). In the field, honeybee colonies can suffer from multiple virus infections without showing obvious pathological symptoms, thereby confounding diagnoses. A rapid and accurate diagnosis for virus infection, therefore, is a critical component of honeybee disease surveillance and control programs.

In these years the development of bio-molecular assays has offered a rapid, sensitive and specific approach to honeybee viruses' identification. These assays, differently from serological analysis (low sensitivity and low speci- 
ficity), are able to detect latent infections of the colony (Benjeddou et al., 2001; Grabensteiner et al., 2001; Bakonyi et al., 2002a, 2002b; Ribière et al., 2002; Fujiyuki et al., 2004; Yue and Genersch, 2005; Chen and Siede, 2007a, 2007b; Teixeira et al., 2008).

Finally, in the absence of long-term epidemiological surveys and specifically dedicated protocols, the possible emergence of viral diseases of bees and their impact may have remained unseen and impossible to assess. Epidemiological studies could provide key information to design surveillance programs against one the major threat to worldwide beekeeping.

\section{References}

Allen MF, Ball BV, 1996. The incidence and world distribution of the honeybee viruses. Bee World 77:141-62.

Allen MF, Ball BV, White RF, Antoniw JF, 1986. The detection of acute paralysis virus in Varroa jacobsoni by the use of a simple indirect ELISA. J Apicult Res 25:100-5.

Anderson DL, East IJ, 2008. The latest buzz about colony collapse disorder. Science 319:724.

Anderson DL, Gibbs AJ, 1988. Inapparent virus infections and their interactions in pupae of the honeybee (Apis mellifera L.) in Australia. J Gen Virol 69:1617-25.

Antunez K, D’Alessandro B, Corbella E, Zunino $\mathrm{P}, 2005$. Detection of chronic bee paralysis virus and acute bee paralysis virus in Uruguayan honeybees. J Invertebr Pathol 90:69-72.

Antunez K, D’Alessandro B, Corbella E, Ramallo G, Zunino P, 2006. Honeybee viruses in Uruguay. J Invertebr Pathol 93:67-70.

Aronstein KA, Murray KD, 2010. Chalkbrood disease in honeybees. $\mathrm{J}$ Invertebr Pathol 103:20-9.

Aumeier P, 2001. Bioassay for grooming effectiveness towards Varroa destructor mites in Africanized and Carniolan honeybees. Apidologie 32:81-90.

Bailey L, Ball BV, 1991. Honeybee pathology. Academic Press, London, UK.

Bailey L, Ball BV, Perry JN, 1983. Association of viruses with two protozoal pathogens of the honeybee. Ann Appl Biol 103:13-20.

Bailey L, Ball BV, Woods RD, 1976. An iridovirus from bees. J Gen Virol 31:459-61.

Bailey L, Carpenter JM, Woods RD, 1982. The diminished incidence of Acarapis woodi (Rennie) (Acari: Tarsonelidae) in honeybee, Apis mellifera L. (Hymenoptera: Apidae), in Britain. B Entomol Res 72:65562.

Bailey L, Gibbs AJ, Woods RD, 1964. Sacbrood virus of the larval honeybee (Apis mellifera Linnaeus). Virology 23:425-9.

Bailey L, Gibbs AJ, Woods RD, 1963. Two viruses from adult honeybees (Apis mellifera Linnaeus). Virology 21:390-5.

Bailey L, Gibbs AJ, Woods RD, 1968. The purification and properties of chronic bee-paralysis virus. J Gen Virol 2:251-60.

Bailey L, Woods RD, 1974. Three previously undescribed viruses from the honeybee. $\mathrm{J}$ Gen Virol 25:175-86.

Baker AC, Schroeder DC, 2008. The use of RNA-dependent RNA polymerase for the taxonomic assignment of Picorna-like viruses (order Picornavirales) infecting Apis mellifera L. populations. Virol J 5:10.

Bakonyi T, Farkas R, Szendroi A, Dobos-Kovacs M, Rusvai M, 2002a. Detection of acute bee and Varroa destructor field samples: rapid screening of representative Hungarian apiaries. Apidologie 33:63-74.

Bakonyi T, Grabensteiner E, Kolodziejek J, Rusvai M, Topolska G, Ritter W, Nowotny $\mathrm{N}, 2002 \mathrm{~b}$. Phylogenetic analysis of acute bee paralysis virus strains. Appl Environ Microb 68:6446-50.

Ball BV, Allen M, 1988. The prevalence of pathogens in honeybee (Apis mellifera) colonies infested with the parasitic mite Varroa jacobsoni. Ann Appl Biol 113:23744.

Ball BV, 1983. The association of Varroa jacobsoni with virus diseases of honeybees. Exp Appl Acarol 19:607-13.

Ball BV, 1989. Varroa jacobsoni as a virus vector. In Cavalloro R (ed.) Present status of varroatosis in Europe and progress in varroa mite control. Office for Official Publications of the European Communities, Luxembourg, pp 241-4.

Ball BV, 1999. Paralysis. In: Colin ME, Ball BV, Kilani M (eds.) Bee disease diagnosis. CIHEAM Publ., Zaragoza, Spain, pp 81-9.

Baudry E, Solignac M, Garnery L, Gries M, Cornuet JM, Koeniger N, 1998. Relatedness among honeybees (Apis mellifera) of a drone congregation. P Roy Soc B 265:2009-14.

Békési L, Ball BV, Dobos-Kovács M, Bakonyi T, Rusvai M, 1999. Occurrence of acute paralysis virus of the honeybee (Apis mellifera) in a Hungarian apiary infested with the parasitic mite Varroa jacobsoni. Acta Vet Hung 47:319-24.

Benjeddou M, Leat N, Allsopp M, Davison S, 2001. Detection of Acute Bee Virus and Black Queen Cell Virus from honeybees by reverse transcriptase PCR. Appl Environ Microb 67:2384-7.

Berenyi 0, Bakonyi T, Derakhshifar I, Koglberger H, Nowotny N, 2006. Occurrence of six honeybee viruses in diseased Austrian Apiaries. Appl Environ Microb 72:2414-20.
Blanchard P, Olivier V, Iscache AL, Celle 0, Schurr F, Lallemand P, Ribière M, 2008. Improvement of RT-PCR detection of chronic bee paralysis virus (CBPV) required by the description of genomic variability in French CBPV isolates. J Invertebr Pathol 97:182-5.

Blanchard P, Ribiere M, Celle 0, Lallemand P, Schurr F, Olivier V, Iscache AL, Faucon JP, 2007. Evaluation of a real-time two-step RT-PCR assay for quantitation of Chronic bee paralysis virus (CBPV) genome in experimentally-infected bee tissues and in life stages of a symptomatic colony. J Virol Methods 141:7-13.

Blazyte-Cereskiene L, Vaitkeviciene G, Venskutonyte S, Buda V, 2010. Honeybee foraging in spring oil seed rape crops under high ambient temperature conditions. Zemdirbyste 97:61-70.

Boylan-Pett W, Ramsdell DC, Hoopingarner RA, Hancock JF, 1991. Honeybee foraging behaviour, in-hive survival of infectious, pollen-borne blueberry leaf mottle virus and transmission of the virus in highbush blueberry. Phytopathology 81:1407-12.

Breeze TD, Bailey AP, Baelcombe KG, Potts G, 2011. Pollination services in the UK: how important are honeybees? Agr Ecosyst Environ 142:137-43.

Brodschneider R, Crailsheim K, 2010. Nutrition and health in honeybees. Apidologie 41:278-94.

Brødsgaard CJ, Ritter W, Hansen H, Brødsgaard HF, 2000. Interactions among Varroa jacobsoni mites, acute paralysis virus, and Paenibacillus larvae larvae and their influence on mortality of larval honeybees in vitro. Apidologie 31:543-54.

Bromenshenk JJ, Henderson CB, Wick CH, Stanford MF, Zulich AW, Jabbour RE, Deshpande SV, McCubbin PE, Seccomb RA, Welch PM, Williams T, Firth DR, Skowronski E, Lehmann MM, Bilimoria SL, Gress J, Wanner KW, Cramer RA Jr., 2010. Iridovirus and microsporidian linked to honeybee colony decline. PLoS One 5:13181.

Chantawannakul P, Ward L, Boonham N, Brown M, 2006. A scientific note on the detection of honeybee viruses using realtime PCR (TaqMan) in Varroa mites collected from a Thai honeybee (Apis mellifera) apiary. J Invertebr Pathol 91:69-73.

Chen YP, Evans J, Feldlaufer MF, 2006a. Horizontal and vertical transmission of viruses in the honeybee, Apis mellifera. $\mathrm{J}$ Invertebr Pathol 92:152-9.

Chen YP, Higgins JA, Feldlaufer MF, 2005a. Quantitative real-time reverse transcription-PCR analysis of deformed wing virus infection in the honeybee (Apis mellifera L.). Appl Environ Microb 71:436-41.

Chen YP, Pettis JS, Collins A, Feldlaufer MF, 
2006b. Prevalence and transmission of honeybee viruses. Appl Environ Microb 72:606-11.

Chen YP, Pettis JS, Feldlaufer MF, 2005b. Detection of multiple viruses in queens of the honeybee Apis mellifera L. J Invertebr Pathol 90:118-21.

Chen YP, Siede R, 2007a. Honeybee viruses. Adv Virus Res 70:33-80.

Chen YP, Siede R, 2007b. Honeybee viruses. In: Maramorosh K, Shatkin AJ, Murphy FA, eds. Advances in virus research. Elsevier Academic Press, Amsterdam, The Netherlands, pp 34-80.

Chen YP, Zhao Y, Hammond J, Hei-ti H, Evans J, Feldlaufer MF, 2004. Multiple virus infections in the honeybee and genome divergence of honeybee viruses. $\mathrm{J}$ Invertebr Pathol 87:84-93.

Christian PD, Scotti PD, 1998. Picorna like viruses of insects. In: Miller LK, Ball LA (eds.), The insect viruses. Plenum Publishing Corporation, New York, USA, pp 301-36.

Clayton DH, Tompkins DM, 1994. Ectoparasite virulence is linked to mode of transmission. P Roy Soc B 256:211-7.

Cox-Foster D, van Engelsdorp D, 2009. Solving the mystery of the disappearing bees. Sci Am 2009:40-7.

Cox-Foster DL, Conlan S, Holmes EC, Palacios G, Evans JD, Moran NA, Quan P, Briese T, Hornig M, Geiser DM, Martinson V, van Engelsdorp D, Kalkstein AL, Drysdale A, Hui J, Zhai J, Cui L, Hutchison SK, Simons JF, Egholm M, Pettis JS, Lipkin WI, 2007. A metagenomic survey of microbes in honeybee colony collapse disorder. Science 318:283-7.

Crane E, 1978. The Varroa mite. Bee World 59:164-7.

Crotti E, Sansonno L, Prosdocimi EM, Vacchini V, Hamdi C, Cherif A, Gonella E, Marzorati M, Balloi A, 2013. Microbial symbionts of honeybees: a promising tool to improve honeybee health. New Biotechnol 30:6

Dainat B, Ken T, Berthoud H, Neumann P, 2009. The ectoparasitic mite Tropilaelaps mercedesae (Acari, Laelapidae) as a vector of honeybee viruses. Insect Soc 56:403 .

Dall DJ, 1985. Inapparent infection of honeybee pupae by Kashmir and Sacbrood bee viruses in Australia. Ann Appl Biol 106:461-8.

de Jong D, De Jong PH, Goncalves LS, 1982. Weight loss and other damage to developing worker honeybees from infestation with Varroa jacobsoni. J Apicult Res 21:165-7.

de Miranda JR, Cordoni G, Budge G, 2010a. The Acute bee paralysis virus-Kashmir bee virus-Israeli acute paralysis virus complex. J Invertebr Pathol 103:30-47. de Miranda JR, Drebot M, Tyler S, Shen M, Cameron CE, Stoltz DB, Camazine SM, 2004. Complete nucleotide sequence of Kashmir bee virus and comparison with acute bee paralysis virus. J Gen Virol 85:2263-70.

de Miranda JR, Fries I, 2008. Venereal and vertical transmission of deformed wing virus in honeybees (Apis mellifera L.). J Invertebr Pathol 98:184-9.

de Miranda JR, Genersch E, 2010b. Deformed wing virus. J Invertebr Pathol 103:48-61.

Desneux N, Decourtye A, Delpuech JM, 2007. The sublethal effects of pesticides on beneficial arthropods. Annu Rev Entomol 52:81-106.

Ellis JD, Munn PA, 2005. The worldwide health status of honeybees. Bee World 86:88-101.

Estoup A, Solignac M, Cornuet JM, 1994. Precise assessment of the number of patrilines and of genetic relatedness in honeybee colonies. P Roy Soc B 258:1-7.

Evans JD, 2001. Genetic evidence for co-infection of honeybees by acute bee paralysis and Kashmir bee viruses. $\mathrm{J}$ Invertebr Pathol 78:189-93.

Evans JD, Schwarz RS, 2011. Bees brought to their knees: microbes affecting honeybee health. Trends Microbiol 19:614-20.

Ewald PW, 1994. Evolution of infectious diseases. Oxford University Press, Oxford, UK.

Farkas R, Bakonyi T, Börzsönyi L, Rusvai M, 2001. Questionnaire examination for the infection of honeybee (Apis mellifera L.) with Varroa jacobsoni Oudemans in domestic apiaries. Magyar Allatorvosok Lapja 123:348-53.

Faucon JP, 1992. Paralyse chronique ou maladie noire. In: CNEVA (ed.) Précis de pathologie: connaitre et traiter les maladies des abeilles. CNEVA-FNOSAD, SophiaAntipolis, France, pp 204-12.

Fauquet CM, Mayo MA, Maniloff J, Desselberger U, Ball LA, 2005. Virus taxonomy: eighth report of the international committee on taxonomy of viruses. Elsevier Academic Press, London, UK.

Fievet J, Tentcheva D, Gauthier L, de Miranda $\mathrm{J}$, Cousserans F, Colin ME, Bergoin M, 2006. Localization of deformed wing virus infection in queen and drone Apis mellifera L. Virol J 3:16.

Forgách P, Bakonyi T, Tapaszti Z, Nowotny N, Rusvai M, 2007. Prevalence of pathogenic bee viruses in Hungarian apiaries: Situation before joining the European Union. J Invertebr Pathol 98:235-8.

Forsgren E, de Miranda JR, Isaksson M,Wei S, Fries I, 2009. Deformed wing virus associated with Tropilaelaps mercedesae infesting European honeybees (Apis mellifera). Exp Appl Acarol 47:87-97.

Free JB, 1993. Insect pollination of crops. $2^{\text {nd }}$ ed. Academy Press, London, UK.

Fries I, Feng F, Da Silva A, Slemenda SB, Pieniazek NJ, 1996. Nosema ceranae n. sp. (Microspora, Nosematidae), morphological and molecular characterization of a microsporidian parasite of the Asian honeybee Apis cerana (Hymenoptera, Apidae). Eur J Protistol 32:356-65.

Fujiyuki T, Ohka S, Takeuchi H, Ono M, Nomoto A, Kubo T, 2006. Prevalence and phylogeny of Kakugo virus, a novel insect Picorna-like virus that infects the honeybee (Apis mellifera L.), under various colony conditions. J Virol 23:11528-38.

Fujiyuki T, Takeuchi H, Ono M, Ohka S, Sasaki T, Nomoto A, Kubo T, 2004. Novel insect picorna-like virus identified in the brains of aggressive worker honeybees. J Virol 78:1093-100.

Gallai N, Salles JM, Settele J, Vaissiere BE, 2009. Economic valuation of the vulnerability of world agriculture confronted with pollinator decline. Ecol Econ 68:810-21.

Genersch E, 2008. Paenibacillus larvae and American foulbrood - long since known and still surprising. J Verbrauch Lebensm 3:429-34.

Ghosh RC, Ball BV, Willcocks MM, Carter MJ, 1999. The nucleotide sequence of sacbrood virus of the honeybee: an insect picornalike virus. J Gen Virol 80:1541-9.

Giauffret A, Duthoit JL, Caucat MJ, 1966a. Etude histologique du tissu nerveux de l'abeille atteinte de maladie noire. Bull Apic 9:221-8.

Gisder S, Aumeier P, Genersch E, 2009. Deformed wing virus: replication and viral load in mites. J Gen Virol 90:463-7.

Glinsky Z, Jarosz J, 1992. Varroa jacobsoni as a carrier of bacterial infections to a recipient bee host. Apidologie 23:25-31.

Govan VA, Leat N, Allsopp M, Davison S, 2000. Analysis of the complete genome sequence of acute bee paralysis virus shows that it belongs to the novel group of insect-infecting RNA viruses. Virology 277:457-63.

Grabensteiner E, Ritter W, Carter MJ, Davison S, Pechhacker H, Kolodziejek J, Boecking 0, Derakhshifar I, Moosbeckhofer R, Licek E, Nowotny N, 2001. Sacbrood Virus of the honeybee (Apis mellifera): rapid identification and phylogenetic analysis using reverse transcription-PCR. Clin Diagn Lab Immun 8:93-104.

Gromeier M, Wimmer E, Gorbalenya AE, 1999. Genetics, pathogenesis and evolution of picornaviruses. In: Domingo E, Webster RG, Holland JJ (eds.) Origin and evolution of viruses. Academic Press, London, UK, pp 287-343.

Heisenberg M, 2003. Mushroom body memoir: from maps to models. Nat Rev Neurosci 4:266-75.

Higes M, Esperón F, Sánchez-Vizcaíno JM, 
2007. First report of black queen-cell virus detection in honeybees (Apis mellifera) in Spain. Span J Agric Res 3:322-5.

Higes M, Martin R, Meana A, 2006. Nosema ceranae, a new microsporidian parasite in honeybees in Europe. $\mathrm{J}$ Invertebr Pathol 92:93-5.

Higes M, Martín-Hernández R, Botías C, Bailón EG, González-Porto AV, Barrios L, Del Nozal MJ, Bernal JL, Jiménez JJ, Palencia PG, Meana A, 2008. How natural infection by Nosema ceranae causes honeybee colony collapse. Environ Microbiol 10:2659-69.

Huang WF, Jiang J-H, Chen Y-W, Wang C-H, 2007. A Nosema ceranae isolate from the honeybee Apis mellifera. Apidologie 38:307.

Hung ACF, 2000. PCR detection of Kashmir bee virus in honeybee excreta. J Apic Res 39:103-6.

Hung ACF, Adams JR, Shimanuki H, 1995. Bee parasitic mite syndrome (II): the role of Varroa mite and virus. Am Bee J 135:7024.

Hung ACF, Shimanuki H, 1999. A scientific note on the detection of Kashmir bee virus in individual honeybees and Varroa jacobsoni mites. Apidologie 30:353-4.

Iqbal J, Mueller U, 2007. Virus infection causes specific learning deficits in honeybee foragers. Pr Roy Soc B 274:1517-21.

Johnson R, 2010. Honeybee colony collapse disorder. CRS report for congress. Available from: https://fas.org/sgp/crs/misc/RL33938.pdf

Kanbar G, Engels W, 2003. Ultrastructure and bacterial infection of wounds in honeybee (Apis mellifera) pupae punctured by Varroa mites. Parasitol Res 90:438.

Kang YB, Kim DS, Jang DH, 1976. Experimental studies on the pathogenicity and developmental stages of Nosema apis. Korean J Vet Res 16:180-4.

Kovac H, Crailsheim K, 1988. Lifespan of Apis mellifera Carnica Pollm. infested by Varroa jacobsoni in relation to season and extent of infestation. J Apic Res 27:230-8.

Lanzi G, Miranda JR, Boniotti MB, Cameron CE, Lavazza A, Capucci L, Camazine SM, Rossi C, 2006. Molecular and biological characterization of deformed wing virus of honeybees (Apis mellifera L.). J Virol 80:4998-5009.

Leat N, Ball B, Govan V, Davison S, 2000. Analysis of the complete genome sequence of black queen-cell virus, a picorna-like virus of honeybees. J Gen Virol 81:2111-9.

Maori E, Lavi S, Mozes-Koch R, Gantman Y, Peretz Y, Edelbaum 0, Tanne E, Sela I, 2007a. Isolation and characterization of Israeli acute paralysis virus, a dicistrovirus affecting honeybees in Israel: evidence for diversity due to intra and inter-species recombination. J Gen Virol 88:3428-38.

Maori E, Paldi N, Shafir S, Kalev H, Tsur E, Glick E, Sela I, 2009. IAPV, a bee affecting virus associated with Colony Collapse Disorder can be silenced by dsRNA ingestion. Insect Mol Biol 18:55-60.

Maori E, Tanne E, Sela I, 2007b. Reciprocal sequence exchange between non retro viruses and hosts leading to the appearance of new host phenotypes. Virology 362:342-49.

Martin SJ, 2001. The role of Varroa and viral pathogens in the collapse of honeybee colonies: a modeling approach. J Appl Ecol 38:1082-93.

Mattila HR, Seeley TD, 2007. Genetic diversity in honeybee colonies enhances productivity and fitness. Science 317:362-4.

Mayer DF, Lunden JD, 1988. Foraging behaviour of honeybees on Manchurian crabapple and red delicious apple. J Entomol Soc Brit Col 83:67-71.

Menzel R, 2001. Searching for the memory trace in a mini-brain, the honeybee. Learn Memory 8:53-62.

Morse RA, Calderone NW, 2000. The value of honeybees as pollinators of US crops in 2000. Bee Cult 128:2-15.

Morton J, Ball R, Brown M, Wilkins S, 2005. Managing Varroa. Department for Environment, Food and Rural AffairsCentral Science Laboratory, London, UK.

Nazzi F, Brown SP, Annoscia D, Del Piccolo F, Di Prisco G, Varricchio P, Della Vedova G, Cattonaro F, Caprio E, Pennacchio F, 2012. Synergistic parasite-pathogen interactions mediated by host immunity can drive the collapse of honeybee colonies. PLoS Pathog 8:1002735.

Nixon M, 1982. Preliminary world maps of honeybee diseases and parasities. Bee World 63:23-42.

Nordström S, 2000. Virus infections and varroa mite infestations in honeybee colonies. $\mathrm{PhD}$ Thesis. Swedish University of Agricultural Sciences, Uppsala, Sweden.

Olivier V, Blanchard P, Chaouch S, Lallemand P, Schurr F, Celle 0, Dubois E, Tordo N, Thiery R, Houlgatte R, Ribière M, 2008a. Molecular characterization and phylogenetic analysis of Chronic bee paralysis virus, a honeybee virus. Virus Res 132:59-68.

Olivier V, Massou I, Celle 0, Blanchard P, Schurr F, Ribière M, Gauthier M, 2008b. In situ hybridization assays for localization of the Chronic bee paralysis virus in the honeybee (Apis mellifera) brain. J Virol Methods 153:232-7.

Ongus JR, Peters D, Bonmatin JM, Bengsch E, Vlak JM, van Oers MM, 2004. Complete sequence of a picorna-like virus of the genus Iflavirus replicating in the mite Varroa destructor. J Gen Virol 85:3747-55.

Overton HA, Buck KW, Bailey L, Ball BV, 1982.
Relationships between the RNA components of chronic bee-paralysis virus and those of chronic bee-paralysis virus associate. J Gen Virol 63:171-9.

Palacios G, Hui J, Quan PL, Kalkstein A, Honkavuori KS, Bussetti AV, Conlan S., Evans, J., Chen, YP., van Engelsdorp D, Efrat H, Pettis J, Cox-Foster D, Holmes EC, Briese T, Lipkin WI, 2008. Genetic analysis of Israel Acute Paralysis Virus: distinct clusters are circulating in the United States. J Virol 82:6209-17.

Paxton R, Klee J, Korpela S, Fries I, 2007. Nosema ceranae has infected Apis mellifera in Europe since at least 1998 and may be more virulent than Nosema apis. Apidologie 38:558-65.

Pettis J, Van engelsdorp D, Cox-Foster D, 2007. Colony collapse disorder working group pathogen sub-group progress report. Am Bee J 147:595-7.

Pettis JS, 2008. Status of colony losses in the US. In: OIE-Apimondia, ed. Proceedings of the Symposium on Diagnosis and Control of Bee Diseases, 19-20 September, Buenos Aires/Argentina. OIE and Apimondia, Freiburg, Germany.

Reyes-Carrillo JL, Eischen FA, Cano-Rios P, Rodriguez- Martinez R, Camberos UN, 2007. Pollen collection and honeybee forage distribution in Cantaloupe. Acta Zool Mex 23:29-36.

Reynaldi FJ, Sguazza GH, Pecoraro MR, Tizzano MA, Galosi CM, 2010. First report of viral infections that affect Argentinean honeybee. Environ Microbiol Reports 2:749-51.

Reynaldi FJ, Sguazza GH, Tizzano MA, Fuentealba NA, Galosi CM, Pecoraro MR, 2011. First report of Israeli acute paralysis virus in asymptomatic hives of Argentina. Rev Argent Microbiol 43:84-6.

Ribière M, Ball BV, Aubert MFA, 2008. Natural history and geographic distribution of honeybee viruses. In: Aubert MFA, Ball BV, Fries I, Milani N, Morritz RFA (eds.) Virology and the honeybee. EC Publications, Brussels, Belgium, pp 15-84.

Ribière M, Lallemand P, Iscache AL, Schurr F, Celle 0, Blanchard P, Olivier V, Faucon JP, 2007. Spread of infectious chronic bee paralysis virus by honeybee (Apis mellifera L.) feces. Appl Environ Microb 73:77116.

Ribière M, Olivier V, Blanchard P, 2010. Chronic bee paralysis: a disease and a virus like no other? J Invertebr Pathol 103:120-31.

Ribière $\mathrm{M}$, Triboulot $\mathrm{C}$, Mathieu L, Aurieres $\mathrm{C}$, Faucon JP, Pepin M, 2002. Molecular diagnosis of chronic bee paralysis virus infection. Apidologie 33:339-51.

Rortais A, Tentcheva D, Papachristoforou A, Gauthier L, Arnold G, Colin ME, Bergoin M, 
2006. Deformed wing virus is not related to honeybees' aggressiveness. Virol J 3:61.

Runckel C, Flenniken ML, Engel JC, Ruby JG, Ganem D, Andino R, De Risi JL, 2011. Temporal analysis of the honeybee microbiome reveals four novel viruses and seasonal prevalence of known viruses, Nosema, and Crithidia. Plos One 6:e20656.

Sammataro D, Gerson U, Needham G, 2000. Parasitic mites of honeybees: life history, implications, and impact. Annu Rev Entomol 45:519-48.

Sanpa S, Chantawannakul P, 2009. Survey of six bee viruses using RT-PCR in Northern Thailand. J Invertebr Pathol 100:116-9.

Schildberger K, 1983. Local interneurons associated with the mushroom bodies and the central body in the brain of Acheta domesticus. Cell Tissue Res 230:573-86.

Shah KS, Evans EC, Pizzorno MC, 2009. Localization of deformed wing virus (DWV) in the brains of the honeybee, Apis mellifera Linnaeus. Virol J 6:182.

Shen M, Cui L, Ostiguy N, Cox-Foster D, 2005. Intricate transmission routes and interactions between picorna-like viruses (Kashmir bee virus and sacbrood virus) with the honeybee host and the parasitic varroa mite. J Gen Virol 86:2281-9.

Shimanuki H, Calderone NW, Knox DA, 1994. Parasitic mite syndrome: the symptoms. Am Bee J 134:827-8.

Shimanuki H, Knox DA, 1997. Bee health and international trade. Rev Sci Tech 16:172-6.

Southwick EE, Southwick L Jr, 1992. Estimating the economic value of honeybees (Hymenoptera: Apidae) as agricultural pollinators in the United States. J Econ Entomol 85:621-33.

Stoltz D, Shen XR, Boggis C, Sisson G, 1995. Molecular diagnosis of Kashmir bee virus infection. J Apic Res 34:153-60.

Strauss R, 2002. The central complex and the genetic dissection of locomotor behaviour. Curr Opin Neurobiol 12:633-8.

Sumpter DJT, Martin SJ, 2004. The dynamics of virus epidemics in Varroa-infested honeybee colonies. J Anim Ecol 73:51-63.

Sushil SN, Stanley J, Hedau NK, Bhatt JC, 2013. Enhancing seed production of three Brassica vegetables by honeybee pollination in north-western Himalayas of India. Univ J Agr Res 1:49-53.

Swinton SM, Lupi F, Robertson GP, Hamilton SK, 2007. Ecosystem services and agriculture: cultivating agricultural ecosystems for diverse benefits. Ecol Econ 64:245-52.

Teixeira EW, Chen Y, Message D, Pettis J,
Evans JD, 2008. Virus infections in Brazilian honeybees. J Invertebr Pathol 99:117-9.

Tentcheva D, Gauthier L, Bagny L, Fievet J, Dainat B, Cousserans F, Colin ME, Bergoin M, 2006. Comparative analysis of deformed wing virus (DWV) RNA in Apis mellifera L. and Varroa destructor. Apidologie 37:41-50.

Tentcheva D, Gauthier L, Zappulla N, Dainat B, Cousserans F, Colin ME, Bergoin M, 2004. Prevalence and seasonal variations of six bee viruses in Apis mellifera L. and Varroa destructor mite populations in France. Appl Environ Microb 70:7185-91.

Terio V, Martella V, Camero M, Decaro N, Testini G, Bonerba E, Tantillo G, Buonavoglia C, 2008. Detection of a honeybee Iflavirus with intermediate characteristics between kakugo virus and deformed wing virus. New Microbiol 31:439-44.

Todd JH, de Miranda JR, Ball BV, 2007. Incidence and molecular characterization of viruses found in dying New Zealand honeybee (Apis mellifera) colonies infested with Varroa destructor. Apidologie 38:354-67.

Valles SM, Strong CA, Oi DH, Porter SD, Pereira RM, Vander Meer RK, Hashimoto Y, Hooper-Búi LM, Sánchez-Arroyo H, Davis T, Karpakakunjaram V, Vail KM, Graham LC, Briano JA, Calcaterra LA, Gilbert LE, Ward R, Ward K, Oliver JB, Taniguchi G, Thompson DC, 2007. Phenology, distribution, and host specificity of Solenopsis invicta virus-1. J Invertebr Pathol 96:18-27.

van Engelsdorp D, Caron D, Hayes J, Underwood R, Henson M, Rennich K, Spleen A, Andree M, Snyder R, Lee K, Roccasecca K, Wilson M, Wilkes J, Lengerich E, Pettis J, 2012. A national survey of managed honeybee 2010-11 winter colony losses in the USA: results from the Bee Informed Partnership. J Apicult Res 51:115-24.

van Engelsdorp D, Evans JD, Donovall L, Mullin C, Frazier M, Frazier J, Tarpy DR, Hayes Jr J, Pettis JS, 2009. "Entombed Pollen": a new condition in honeybee colonies associated with increased risk of mortality. J Invertebr Pathol 101:71-6.

van Engelsdorp D, Hayes J, Underwood RM, Pettis J, 2008. A survey of honeybee colony losses in the U.S., fall 2007 to spring 2008. PLoS One 3:4071.

van Engelsdorp D, Meixner MD, 2010. A histo- rical review of managed honeybee populations in Europe and the United States and the factors that may affect them. J Invertebr Pathol 103:80-95.

van Engelsdorp D, Underwood RM, Caron D, Hayes J, 2007. An estimate of managed colony losses in the winter of 2006-2007: a report commissioned by the Apiary Inspectors of America. Am Bee J 147:599603 .

Wessnitzer J, Webb B, 2006. Multimodal sensory integration in insects: towards insect brain control architectures. Bioinspir Biomim 1:63-75.

White GF, 1913. Sacbrood, a disease of bees. US Department of Agriculture, Bureau of Entomology, Washington, DC, USA.

Wikel SK, 1999. Tick modulation of host immunity: an important factor in pathogen transmission. Int J Parasitol 29:851-9.

Yang X, 2004. Effects of Varroa mites on the immune system and pathology of honeybees. PhD thesis. The Pennsylvania State University, State College, PA, USA.

Yang X, Cox-Foster D, 2007. Effects of parasitization by Varroa destructor on survivorship and physiological traits of Apis mellifera in correlation with viral incidence and microbial challenge. Parasitology 134:40512.

Yang X, Cox-Foster DL, 2005. Impact of an ectoparasite on the immunity and pathology of an invertebrate: evidence for host immunosuppression and viral amplification. P Natl Acad Sci USA 102:7470-5.

Yue C, Genersch E, 2005. RT-PCR analysis of deformed wing virus in honeybees (Apis mellifera) and mites (Varroa destructor). J Gen Virol 86:3419-24.

Yue C, Schröder M, Bienefeld K, Genersch E, 2006. Detection of viral sequences in semen of honeybees (Apis mellifera): evidence for vertical transmission of viruses through drones. J Invertebr Pathol 92:1058.

Yue C, Schröder M, Gisder S, Genersch E, 2007. Vertical-transmission routes for deformed wing virus of honeybees (Apis mellifera). J Gen Virol 88:2329-36.

Zander E, 1909. Tierische parasiten als krankenheitserreger bei der biene. Münchener Bienenzeitung 31:196-204.

Zhang Q, Ongus JR, Boot WJ, Calis J, Bonmatin J-M, Bengsch E, Peters D, 2007. Detection and localisation of picorna-like virus particles in tissues of Varroa destructor, an ectoparasite of the honeybee, Apis mellifera. J Invertebr Pathol 96:97-105. 